\title{
Influence of Organizational Culture on Teachers' Organizational Commitment and Job Satisfaction: The Case of Catholic Higher Education Institutions in the Philippines
}

\author{
Ma. Leodevina C. Batugal ${ }^{1, *}$, Darin Jan C. Tindowen ${ }^{2}$ \\ ${ }^{1}$ Saint Paul University Philippines, Philippines \\ ${ }^{2}$ University of Saint Louis, Philippines
}

Received April 15, 2019; Revised October 7, 2019; Accepted October 17, 2019

Copyright $\mathrm{C} 2019$ by authors, all rights reserved. Authors agree that this article remains permanently open access under the terms of the Creative Commons Attribution License 4.0 International License

\begin{abstract}
This article examines the influence of organizational culture on the organizational commitment and job satisfaction of teachers in the context of Catholic higher education institutions in the Philippines. Results show that clan is the most dominant culture type of Catholic HEIs in the Philippines. In addition, teachers are highly committed to their organization and satisfied to their job. Furthermore, among the four culture types, clan has a high positive influence on the organizational commitment of teachers and has a slightly positive influence on their job satisfaction. Implications and directions for future research are also discussed.
\end{abstract}

Keywords Organizational Culture, Organizational Commitment, Job Satisfaction, Teachers, Catholic Higher Education Institutions

\section{Introduction}

Through the years, human resources are considered as the most important assets in any organization. Human resources are the moving force of an organization and harnessing their capabilities will contribute much in bringing about quality and productivity (Tindowen, 2019; Wright \& McMahan, 2011; Ployhart \& Molterno, 2011). Because persons are vital in organizations, it is then necessary that top level management should treat them as the utmost priority.

This is also true in the educational setting (Secundo, Margherita, Elia, \& Passiante, 2010; Raj Adhikari, 2010). Teachers play a very important role in the success and sustainability of the organization (Wiesner \& Yuniarti,
2018; Byun \& Kim, 2011; Lane \& McAndrew, 2010) especially in the delivery of quality instruction and education to the students (Calderon, Slavin, \& Sanchez, 2011; Thoonen, Sleegers, Oort, Peetsma, \& Geijsel, 2011). Hence, educational administrators should see to it that their teachers are satisfied to their profession and committed to the organization. In fact, a substantial number of literature and studies had proven that employees who are satisfied on their jobs manifest loyalty to the organization (Hoyt, 2012; Salehi \& Gholtash, 2011; Lim, 2010; Gokce, 2013). In fact, they also tend to perform well and work well for the love of their work. Employees with high job satisfaction level are related to a pro-social behavior that is, having a helpful behavior to customers, co-workers and supervisors to the benefit of the employees and their organization (Thomas, 2010; Fatima, Amiraa, \& Halim, 2011). On the other hand, dissatisfied employees with negative behavior lead to poor service, destructive rumors, and even theft which can lead to employees' absenteeism and fast turnover (Malik, Nawab, Naeem, \& Danish, 2010; Mawoli \& Babandako, 2011). With these, organizational commitment and job satisfaction are considered integral part of the organization in order to maintain quality, development, and sustainability. Hence, these two indicators should not be underestimated by educational administrators and supervisors.

However, despite numerous studies conducted, looking into the organizational commitment and job satisfaction of teachers in their organization, still the results are confusing (Nagar, 2012; Nawab \& Bhatti, 2011; Awang, Ahmad, \& Zin, 2010; Yucel \& Bektas, 2012). Moreover, majority of the studies conducted focused on the teachers of primary and secondary teachers (Naderi Anari, 2012; Cerit, 2010; Hulpia, Devos, \& Rosseel, 2009; Canrinus, Helms-Lorenz, 
Beijaard, Buitink, \& Holfman, 2012). In addition, studies conducted on Higher Education institutions were focused on teachers in government and public owned institutions (Rose, Kumar, \& Pak, 2009; Perrachione, Petersen, \& Rosser, 2008; Okpara \& Wynn, 2008). Finally, studies on organizational commitment and job satisfaction of college teachers were limited and available on developing countries (Moynihan \& Pandey, 2007; Chan, Lau, Nie, Lim, \& Hogan, 2008) such as the Philippines (Brown \& Sageant, 2007; Ereno \& Nunez, 2014) were a huge gap can be manifested in which public and government owned school are at par with private educational institutions in terms of security and tenure, compensation and benefits, and workloads and conditions (Yamauchi, 2005).

Meanwhile, among the different indicators of organizational behaviors in the schools such as organizational commitment and job satisfaction, one important indicator is also considered that may have a profound influence on teachers' work behavior which is organizational culture (Lindahl, 2006; Sarros, Cooper, \& Santora, 2008). Organizational culture comprises the attitudes, experiences, beliefs and values of an organization which are shared by people and groups in an organization and that control the way they interact with each other and with stakeholders outside the organization (Cameron \& Quinn, 1999; Hartnell, Ou, \& Kinicki, 2011). Previous studies had been conducted emphasizing the vital role organizational culture plays in organizations (Fralinger \& Olson, 2007). However, limited studies had been conducted in determining its role in Higher Educational Institutions (Hemmelgarn, Glisson, \& James, 2006; Louis, 2007; Hatcher, 2005) and its important influence on teachers' organizational commitment and job satisfaction (Huey Ying \& Zaman Bin Ahmad, 2009).

\section{Organizational Culture}

Organizational culture is a set of values that help people in an organization understand which actions are considered acceptable and which are considered unacceptable (Cameron, 2008). These are specific collection of values and norms that are shared by people and groups in the organization and that control the way they interact with each other and with stakeholders outside the organization. Organizational culture is consists of six dimensions which are dominant characteristics, organizational leadership, management of employees, organization glue, strategic emphases, and criteria of success. Each of these dimensions has four culture types which are adhocracy, clan, hierarchy, and market (Cameron \& Quinn, 1999; Masood, Dani, Burns, \& Backhouse, 2006).

Adhocracy - it is a culture profile of an organization that concentrates on external positioning with a high degree of flexibility and individuality.

Clan - it is a culture profile of an organization that concentrates on internal maintenance with flexibility, concern for people, and sensitivity for customers.

Hierarchy - it is a culture profile of an organization that focuses on internal maintenance with a need for stability and control.

Market - it is a culture profile of an organization that focuses on external maintenance with a need for stability and control. 


\begin{tabular}{|c|c|c|c|c|}
\hline \multirow{2}{*}{$\begin{array}{l}\text { Organizational } \\
\text { Culture }\end{array}$} & \multicolumn{4}{|c|}{ Culture Type } \\
\hline & Clan & Hierarchy & Adhocracy & Market \\
\hline $\begin{array}{c}\text { Dominant } \\
\text { Characteristics }\end{array}$ & $\begin{array}{l}\text { The organization is a very } \\
\text { personal place. It is like an } \\
\text { extended family where } \\
\text { people seem to share a lot } \\
\text { of themselves. }\end{array}$ & $\begin{array}{l}\text { The organization is a } \\
\text { very dynamic } \\
\text { entrepreneurial place. } \\
\text { The people are willing to } \\
\text { stick their necks out and } \\
\text { take risk. }\end{array}$ & $\begin{array}{l}\text { The organization is very } \\
\text { results oriented. A major } \\
\text { concern is with getting the } \\
\text { job done. People are very } \\
\text { competitive and } \\
\text { achievement oriented. }\end{array}$ & $\begin{array}{l}\text { The organization is a very } \\
\text { controlled and structured } \\
\text { place. Formal procedures } \\
\text { generally govern what } \\
\text { people do. }\end{array}$ \\
\hline $\begin{array}{l}\text { Organizational } \\
\text { Leadership }\end{array}$ & $\begin{array}{l}\text { The leadership in the } \\
\text { organization is generally } \\
\text { considered to exemplify } \\
\text { mentoring, facilitating, or } \\
\text { nurturing. }\end{array}$ & $\begin{array}{l}\text { The leadership in the } \\
\text { organization is generally } \\
\text { considered to exemplify } \\
\text { entrepreneurship, } \\
\text { innovating or risk taking. }\end{array}$ & $\begin{array}{l}\text { The leadership in the } \\
\text { organization is generally } \\
\text { considered to exemplify a } \\
\text { no-nonsense aggressive, } \\
\text { results-oriented focus. }\end{array}$ & $\begin{array}{l}\text { The leadership in the } \\
\text { organization is generally } \\
\text { considered to exemplify } \\
\text { coordinating, organizing, } \\
\text { or smooth-running } \\
\text { efficiency. }\end{array}$ \\
\hline $\begin{array}{l}\text { Management of } \\
\text { Employees }\end{array}$ & $\begin{array}{l}\text { The management style in } \\
\text { the organization is } \\
\text { characterized by teamwork, } \\
\text { consensus, and } \\
\text { participation. }\end{array}$ & $\begin{array}{l}\text { The management style in } \\
\text { the organization is } \\
\text { characterized by } \\
\text { individual risk taking, } \\
\text { innovation, freedom, and } \\
\text { uniqueness. }\end{array}$ & $\begin{array}{l}\text { The management style in } \\
\text { the organization is } \\
\text { characterized by } \\
\text { hard-driving } \\
\text { competitiveness, high } \\
\text { demands, and achievement. }\end{array}$ & $\begin{array}{l}\text { The management style in } \\
\text { the organization is } \\
\text { characterized by security of } \\
\text { employment, conformity, } \\
\text { predictability, and stability } \\
\text { in relationships. }\end{array}$ \\
\hline $\begin{array}{l}\text { Organizational } \\
\text { Glue }\end{array}$ & $\begin{array}{l}\text { The glue that holds the } \\
\text { organization together is } \\
\text { loyalty and mutual trust. } \\
\text { Commitment to this } \\
\text { organization runs high. }\end{array}$ & $\begin{array}{l}\text { The glue that holds the } \\
\text { organization together is } \\
\text { commitment to } \\
\text { innovation and } \\
\text { development. }\end{array}$ & $\begin{array}{l}\text { The glue that holds the } \\
\text { organization together is the } \\
\text { emphasis on achievement } \\
\text { and goal accomplishment. } \\
\text { Aggressiveness and } \\
\text { winning are common } \\
\text { themes. }\end{array}$ & $\begin{array}{l}\text { The glue that holds the } \\
\text { organization together is } \\
\text { formal rules and policies. } \\
\text { Maintaining a } \\
\text { smooth-running } \\
\text { organization is important. }\end{array}$ \\
\hline $\begin{array}{l}\text { Strategic } \\
\text { Emphases }\end{array}$ & $\begin{array}{l}\text { The organization } \\
\text { emphasizes human } \\
\text { resources, teamwork, } \\
\text { employee commitment, and } \\
\text { concern for people. }\end{array}$ & $\begin{array}{c}\text { The organization } \\
\text { emphasizes acquiring } \\
\text { new resources and } \\
\text { creating new challenges. } \\
\text { Trying new things and } \\
\text { prospecting for } \\
\text { opportunities are valued. }\end{array}$ & $\begin{array}{l}\text { The organization } \\
\text { emphasizes competitive } \\
\text { actions and achievement. } \\
\text { Hitting stretch targets and } \\
\text { winning in the marketplace } \\
\text { are dominant. }\end{array}$ & $\begin{array}{l}\text { The organization } \\
\text { emphasizes permanence } \\
\text { and stability. Efficiency, } \\
\text { control, and smooth } \\
\text { operations are important. }\end{array}$ \\
\hline $\begin{array}{l}\text { Criteria of } \\
\text { Success }\end{array}$ & $\begin{array}{l}\text { The organization defines } \\
\text { success on the basis of the } \\
\text { development of the human } \\
\text { resources, teamwork, } \\
\text { employee commitment, and } \\
\text { concern for people. }\end{array}$ & $\begin{array}{l}\text { The organization defines } \\
\text { success on the basis of } \\
\text { having the most unique } \\
\text { or newest programs. It is } \\
\text { a program leaders and } \\
\text { innovator. }\end{array}$ & $\begin{array}{l}\text { The organization defines } \\
\text { success on the basis of } \\
\text { winning in the marketplace } \\
\text { and outspacing the } \\
\text { competition. Competitive } \\
\text { market leadership is the } \\
\text { key. }\end{array}$ & $\begin{array}{l}\text { The organization defines } \\
\text { success on the basis of } \\
\text { efficiency. Dependable } \\
\text { delivery, smooth } \\
\text { scheduling, and low-cost } \\
\text { operation are critical. }\end{array}$ \\
\hline
\end{tabular}

\section{Organizational Commitment}

Organizational commitment is the psychological attachment of an employee to the organization (Meyer \& Allen, 1991). It is characterized as those individuals who attend to work daily, protect organizational assets, share organizational goal, and remain with organization through both good and bad times. There are three dimensions of organizational commitment which are affective commitment, continuance commitment, and normative commitment (Meyer \& Allen, 1991; Balci, 2003; Meyer, Becker, \& Van Dick, 2006; Khan, Shah, Hassan, Khan, \& Khan, 2013).

- Affective Commitment - This refers to the employees' emotional attachment, identification with, and involvement in the organization.

- Continuance Commitment - This refers to the employees' assessment of whether the cost of leaving the organization is greater than the cost of staying.
- Normative Commitment - This refers to the employees' feeling of obligation to the organization.

\section{Job Satisfaction}

Job satisfaction is consists of positive feelings and attitudes an employee has about one's job. It results from the perception that an employee's job actually provides what he or she values in the work situation (Nguini, Sleegers, \& Denessen, 2006; Evans, 2001; Bogler, 2001). Among the different literature that were conducted on job satisfaction of teachers especially in higher education institutions, the following were considered as important aspects for job satisfactions which are relationships in the working environment (Crossman \& Harris, 2006; ), compensation and remuneration, school and physical environment (Collie, Shapka, \& Perry, 2012; Skaalvik \& Skaalvik, 2009), administrative policies and support (Duffy \& Lent, 2009), and overall management (Huysman, 2007; Santhapparaj \& Alam, 2005). 


\section{Method}

\subsection{Respondents}

The respondents of the study consisted of 129 faculty members sampled from four Catholic Higher Education Institutions in the Philippines. However, only lay faculty members who are full-time and with permanent status were considered in the study. Table 1 shows the background variables of the respondents. Of the faculty members, $71.23 \%$ are female and most of them age from $31-35$ years old. Moreover, most of them are married and have served their institutions from 6-10 years. Furthermore, most of the respondents hold a master's degree and almost all of them are plain faculty members and do not hold administrative positions

Table 1. Background Variables

\begin{tabular}{|c|c|c|}
\hline Background Variables & $n(N=129)$ & $\%$ \\
\hline \multicolumn{3}{|l|}{ Sex } \\
\hline Male & 43 & 26.36 \\
\hline Female & 95 & 73.64 \\
\hline \multicolumn{3}{|l|}{ Age } \\
\hline $21-25$ years old & 5 & 3.88 \\
\hline 26-30 years old & 17 & 13.18 \\
\hline $31-35$ years old & 34 & 26.36 \\
\hline $36-40$ years old & 21 & 16.28 \\
\hline $41-45$ years old & 17 & 14.18 \\
\hline $46-50$ years old & 14 & 10.85 \\
\hline 51-55 years old & 14 & 10.85 \\
\hline $56-60$ years old & 7 & 5.43 \\
\hline \multicolumn{3}{|l|}{ Civil Status } \\
\hline Single & 34 & 26.36 \\
\hline Married & 93 & 72.09 \\
\hline Widowed & 2 & 1.55 \\
\hline \multicolumn{3}{|l|}{$\begin{array}{c}\text { Number of Years in Present } \\
\text { Employment }\end{array}$} \\
\hline 5 years and below & 22 & 17.05 \\
\hline $6-10$ years & 34 & 26.40 \\
\hline $11-15$ years & 24 & 18.60 \\
\hline $16-20$ years & 19 & 14.70 \\
\hline $21-25$ years & 11 & 8.50 \\
\hline $26-30$ years & 13 & 10.90 \\
\hline 31 years and above & 5 & 3.85 \\
\hline \multicolumn{3}{|l|}{ Educational Attainment } \\
\hline Bachelor's Degree & 3 & 23.25 \\
\hline With MA/MS units & 16 & 12.40 \\
\hline Master's Degree Holder & 51 & 39.53 \\
\hline With Doctorate units & 34 & 26.35 \\
\hline Doctorate Degree Holder & 24 & 18.60 \\
\hline Bachelor of Laws and Letters & 1 & 0.77 \\
\hline \multicolumn{3}{|l|}{ Designation } \\
\hline $\begin{array}{c}\text { Administrative and } \\
\text { Supervisory }\end{array}$ & 25 & 19,38 \\
\hline Teaching/Plain Faculty & 104 & 80.62 \\
\hline
\end{tabular}

\subsection{Research Instruments}

This scientific approach in research employed a descriptive and correlational method of research. A quantitative questionnaire using Likert-type scale was administered to 129 college faculty members. The respondents were instructed to fill out questionnaire that asked a range of items about their commitment on the organization, their job satisfaction, and their organizational culture.

\subsection{Instrument on Organizational Culture}

The organizational culture of teachers was measured using the Organizational Culture Assessment Instrument (OCAI) developed by Cameron and Quinn (1999). The said tool is consists of six groups which are dominant characteristics, organizational leadership, management of employees, organization glue strategic emphases, and criteria of success. Each group has four alternatives: Clan, Hierarchy, Adhocracy, and Market. The respondents will give the highest points to a certain alternative that is very similar to their organization. The two other alternatives are somewhat similar and the last alternative is hardly similar to their organization at all. The respondents will have to make sure that the total of each item is equal to 100 points.

\subsection{Instrument on Organizational Commitment}

The organizational commitment of teachers was measured using the Organizational Commitment Questionnaire developed and modified by Meyer and Allen (2006). The said survey questionnaire has become the dominant model for study of workplace commitment in the world (Meyer, 2006). This model proposes that organizational commitment is experienced by the employee as three simultaneous mindsets encompassing affective, normative, and continuance organizational commitment (Allen 2007). The said tool is consists of 18 items on a 7-point scale (scored from $1=$ strongly disagree to $7=$ strongly agree) involving affective (6 items), continuance (6 items), and normative (6 items).

\subsection{Instrument on Job Satisfaction}

The job satisfaction of teachers was measured using the Job Satisfaction Questionnaire developed by the Saint Paul of Chartres Education Apostolate (SPCEA). The tool is consists of 65 items with thirteen (13) components with five (items) on a 4-point scale (scored from 1= strongly disagree to $4=$ strongly agree) which includes relationship with immediate head, interdepartmental relationship, physical environment, relationship with co-employees, compensation, job identification, overall attitude toward work, clarity of work group, implementation of policies, management, communication, feed backing, and task significance. 


\subsection{Data Analysis}

The data gathered were analyzed using descriptive statistics such as frequency counts and percentage for background variables of the respondents; weighted mean for the organizational commitment, job satisfaction, and organizational culture of the respondents. Pearson-R product correlation was also used to describe the influence of organizational culture on teachers' organizational commitment and job satisfaction.

\section{Results}

Table 2. Descriptive Statistics on the Organizational Culture of Educational Institutions

\begin{tabular}{|c|c|c|}
\hline Organizational Culture & Highest Mean & Culture Type \\
\hline $\begin{array}{c}\text { Dominant } \\
\text { Characteristics }\end{array}$ & 34.21 & Clan \\
\hline $\begin{array}{c}\text { Organizational } \\
\text { Leadership }\end{array}$ & 32.64 & Clan \\
\hline $\begin{array}{c}\text { Management of } \\
\text { Employees }\end{array}$ & 32.49 & Clan \\
\hline Organizational Glue & 30.72 & Clan \\
\hline Strategic Emphasis & 29.86 & Clan \\
\hline Criteria of Success & 31.75 & Clan \\
\hline Total & 31.85 & Clan \\
\hline
\end{tabular}

Table 2 presents the dominant organizational culture of Catholic Higher Education Institutions as assessed by college faculty members. It is shown in the table along the area on dominant characteristics of Catholic Higher Education institutions in the Philippines, the dominant culture type is clan in which these institutions are considered as a very personal place like an extended family. This implies that Catholic institutions give the impression of bringing about a spirit of unity by sharing a lot to their employees. Furthermore, it can also be delved in the results that faculty members are emotionally attached with their institutions since they believed that they their institutions are considered as their homes.

Meanwhile, along organizational leadership, teachers of Catholic Higher Education institutions also assessed their respective organizations with clan as the dominant culture type. This stresses that leadership among Catholic Higher Education institutions in the Philippines is generally considered to exemplify mentoring, facilitating, and nurturing. An organization that demonstrates mentoring helps the employees explore and develop their skills necessary to make the organization become more productive and realize its vision and mission (Berrio, 2003; Linnenluecke, \& Griffiths, 2010). Also, administrators should further help their people grow and see beyond what they are today to what they can become tomorrow (White, Varadarajan, \& Dacin, 2003).

On the one hand, it can also be gleaned on the results along management of employees as one of the dimensions of organizational culture of schools, clan is also the dominant culture type as assessed by teachers. This means that Catholic Higher Education institutions in the Philippines are characterized by teamwork, consensus, and participation among administrators and teachers. Many studies had revealed that teamwork is the heart and soul of the organization (Somech \& Khalaili, 2014; Fay, Shilton, West, \& Patterson, 2015). As applied in the workplace, teamwork is a method that aligns employee mindsets in a cooperative and usually self-manner, towards a specific purpose (Herdman, Yang, \& Arthur, 2017). The study reveals that with clan as a dominant management of employee culture style, effective collaboration skills are necessary to work well in a team like the school environment as the schools become larger and more sophisticated. These collaborative efforts help the people in the organization effectively work together in a cohesive group to accomplish shared goals (Hu \& Liden, 2015).

On the other hand, in terms of organizational glue as a dimension of organizational culture of educational institutions, it is revealed that clan is also the dominant culture type. This means that loyalty, mutual trust and commitment run in the organization. The results may imply that teachers value more an organization where there is loyalty and mutual trust among administrators and faculty members. These values as perpetrated create conditions that motivate and energize employees in their work, build and sustain trust in their heads as well as promote and cultivate commitment to the organization (Wiewiora, Trigunarsyah, Murphy, \& Coffey, 2013). With this, the achievement of employees becomes reinforcing because they become self-directing, receptive to greater responsibilities and be converted to leaders themselves.

Further, the table also presented that dominant culture type of educational institutions along strategic emphasis is also clan. This means that Catholic educational institutions are strong on human development as manifested in the high level of trust, openness, and participation that currently exists in the organization.

And finally, along criteria of success, the respondents assessed Catholic Higher Education institutions observe clan as a culture type. This means that what are being emphasized by these schools are human resources, teamwork, employee commitment, and concern for people. In summary, the most dominant organizational culture of Catholic Higher Education institutions in the Philippines is clan.

Table 3. Descriptive Statistics on the Organizational Commitment of Teachers

\begin{tabular}{|c|c|}
\hline Organizational Commitment & $M$ \\
\hline Affective Commitment & $5.42^{\mathrm{a}}$ \\
\hline Continuance Commitment & $4.66^{\mathrm{a}}$ \\
\hline Normative Commitment & $5.45^{\mathrm{a}}$ \\
\hline Total & $5.18^{\mathrm{a}}$ \\
\hline
\end{tabular}

${ }^{\mathrm{a}} 4.61-5.80-$ High. 
Table 3 presents the organizational commitment of faculty members of Catholic Higher Education Institutions in the Philippines. Along affective commitment, the results revealed that the respondents are highly committed to their organization. This implies that teachers are happy to spend the rest of their career in their organization. Hence, they are somewhat decided to stay in their school and willing to spend more years to serve their institution. With this, the respondents are emotionally attached to their institution which is a manifestation of their caring attitude towards their institution. Their high level of affective commitment to their institutions coincide with the results of previous studies in which their attachment is attributed to the relationship they have with their fellow employees, that is they can relate well despite their differences (Casimir, Ngee Keith Ng, Yuan Wang, \& Ooi, 2014; Vandenberghe, Bentein, \& Panaccio, 2014). Also, their desire to remain with the organization is also due to the fact that they can find themselves as being part of the productivity and success of the organization. More importantly, their affective commitment is a manifestation of their belief and appreciation of their institutional values which also represents the gospel and Catholic values in general. This may hold true to Catholic schools in general in which Catholic teachers have a strong commitment to their institution since they share the same vision and mission guided with their personal values that coincides with the teachings of the Catholic Church (Schreiner, 2015).

Meanwhile, it can also be reflected on the table that teachers of Catholic Higher Education Institutions in the Philippines also have a high level of continuance commitment to their organization. With this result, it can be stressed that the respondents feel it practical to remain in their institution and leaving the institution means having no assurance of being employed immediately when they apply for a new job. Previous literature on continuance commitment revealed that the reluctance of the employees to leave the organization is due to the fact that too much of their life would be disrupted if they decide to leave their organization now (Ahluwalia \& Preet, 2016; Mclerney, Ganotice, King, Morin, \& Marsh, 2015) and also the fact that work is a necessity (Joseph, Buela, \& Rajalakshmi, 2017) especially in countries, such as the Philippines were economic situation is unstable, and that financial security and flexibility is necessary for employees (Thang \& Fassin, 2017; Tolentino, 2013).

Finally, in terms of the normative commitment of teachers, it was also revealed that their commitment is high. This means that the respondents believe that it would not be right for them to leave their institution now because they have still moral obligation to the people, to their students, to the parents, to their fellow employees, and to their administrators. And with this, they maintain their membership and commitment to the organization. Previous studies on normative commitment identified some factors that affects employees' normative commitment which were also revealed in the study such as teachers availed scholarships and study leaves and professional development activities that enhanced their career growth such as exposure to national and international seminars and conferences (John, 2017; Yahaya \& Ebrahim, 2017). This premise suggests that employees who availed of these packages feel obliged to have return service to their institution and it would unethical if they leave their organization now without finishing their contracts with their institution.

Table 4. Descriptive Statistics on the Job Satisfaction of Teachers

\begin{tabular}{|c|c|}
\hline Job Satisfaction & $M$ \\
\hline Relationship with Immediate Head & $3.19^{\mathrm{a}}$ \\
\hline Interdepartmental Relationship & $2.87^{\mathrm{a}}$ \\
\hline Physical Environment & $3.11^{\mathrm{a}}$ \\
\hline Relationship with Co-employees & $3.17^{\mathrm{a}}$ \\
\hline Compensation & $2.75^{\mathrm{a}}$ \\
\hline Job Identification & $3.29^{\mathrm{b}}$ \\
\hline Overall Attitude toward Work & $3.26^{\mathrm{b}}$ \\
\hline Clarity of Work Group & $3.18^{\mathrm{a}}$ \\
\hline Implementation of Policies & $2.88^{\mathrm{a}}$ \\
\hline Management & $2.78^{\mathrm{a}}$ \\
\hline Communication & $2.51^{\mathrm{a}}$ \\
\hline Feed Backing & $2.98^{\mathrm{a}}$ \\
\hline Task Significance & $3.30^{\mathrm{b}}$ \\
\hline Total & $3.02^{\mathrm{a}}$ \\
\hline
\end{tabular}

a2.50-3.24 - Satisfied

b3.25 - 4.00 - Very Satisfied

Table 4 presents the job satisfaction of Faculty members of Catholic Higher Education institutions in the Philippines. It can be gleaned in the table that faculty members are very satisfied on their job along job identification, overall attitude toward work, and feed backing. Along their job identification, they are very satisfied with the amount of work they do. This condition is important to consider as a means of attaining higher levels of commitment. Further, the result implies that teachers really value their work especially when they find others are also benefiting from it. This can be a source of their job satisfaction because it implies greater motivation for the faculty members to work harder (Loi, Chan, \& Lam, 2014). The sense of fulfillment in what does truly inspires a reason for finding meaning in his job and a reason for keeping it (Callea, Urbini, \& Chirumbolo, 2016).

Meanwhile, Catholic teachers also are very satisfied on their job in their respective institution along their overall attitude towards their work. This implies a positive outlook of the teachers towards their work. This is a significant character of any institution, the manner by which faculty members see their work with optimism and have a positive feeling towards their work which includes their physical conditions, their work loads, treatment of their supervisors, and their belief on quality (Rayton \& Yalabik, 2014). 
It is also important to note that these Catholic teachers in the Philippines are very satisfied on the feed backing process of their institution. This means that the school administration including the middle level managers and supervisors are consistent in giving feed backs to their employees especially on their job performance, assessments, evaluations, and work improvements. Further, the result also means that the different feed backing processes are very well carried out among the respondents' institutions. Performance evaluation is necessary to improve systems and processes in the organization (Azzopardi \& Nash, 2013). Feed backing processes such as evaluation can accurately outline employees' responsibilities and contributions to an organization and provide valid and important input in personnel decisions (Lazaroiu, 2015). This process, if communicated and properly done, reinforces the link between employee performance and employer satisfaction.

Furthermore, the respondents are satisfied on most of the indicators of job satisfaction which include relationship with their immediate head, interdepartmental relationship, physical environment, relationship with their co-employees, compensation, clarity of work group, implementation of policies, management, communication and task significance. This result implies that generally, faculty members of Catholic Higher Education institutions in the Philippines are pleased with their working conditions in their institution. However, it is important to note that of all the indicators of job satisfaction, communication is rated as the lowest despite still that respondents are satisfied along this area. In any organization, communication is crucial in its operation. There are underlying theories why communication is vital in organization. Communication fosters motivation by classifying what is to be done (Uka, 2014; Koch, 2016; Ruesch, 2017). The formation of specific goals, feedback on progress toward the goal, and reinforcement of desired behavior all stimulate motivation which requires communication. The communication which takes place within the organization is a fundamental mechanism by which the members show their emotional expression which their feelings of frustrations or satisfaction (Zbirenko \& Andersson, 2014). Though generally, the respondents show satisfaction, its implication to management is to become aware that the need to raise the faculty members' satisfaction by focusing on the intrinsic facets of their job which include communication.

Table 5 presents the influence of organizational culture of Catholic Higher Education Institutions in the Philippines to teachers' organizational commitment and job satisfaction. The table shows a high correlation between organizational culture and organizational commitment of teachers. This means that prioritizing clan as the organizational culture of Catholic Educational institutions may eventually lead to higher commitment and loyalty of teachers to their organization. Hence, clan as an organizational behavior positively influences the organizational commitment of teachers. Also, no influence and relationship had been found out with the three culture types which are hierarchy, adhocracy, and market on the organizational commitment of teachers.

Table 5. Significant Relationship of Organizational Culture on Teachers' Organizational Commitment and Job Satisfaction

\begin{tabular}{|c|c|c|c|c|}
\hline \multirow{2}{*}{$\begin{array}{c}\text { Organizational } \\
\text { Culture }\end{array}$} & \multicolumn{2}{|c|}{$\begin{array}{c}\text { Organizational } \\
\text { Commitment }\end{array}$} & \multicolumn{2}{c|}{ Job Satisfaction } \\
\cline { 2 - 5 } & $\begin{array}{c}\text { Pearson- } \\
\mathrm{R}\end{array}$ & $\mathrm{p}$-value & $\begin{array}{c}\text { Pearson- } \\
\mathrm{R}\end{array}$ & $\mathrm{p}$-value \\
\hline Clan & $0.762 \mathrm{~b}$ & $0.001^{*}$ & $0.277 \mathrm{a}$ & $0.002^{*}$ \\
\hline Hierachy & $0.120 \mathrm{c}$ & 0.442 & $-0.190 \mathrm{~d}$ & $0.034^{*}$ \\
\hline Adhocracy & $0.110 \mathrm{c}$ & 0.823 & $-0.272 \mathrm{~d}$ & $0.002^{*}$ \\
\hline Market & $0.112 \mathrm{c}$ & 0.881 & $-0.046 \mathrm{~d}$ & 0.611 \\
\hline
\end{tabular}

*Significant at 0.05 level

a0.21 - $0.40-$ Slight/Low Correlation

b0.71 - 0.90 - High Correlation

c0.00- $0.20-$ Negligible Correlation

d0.00- 0.99 - Negative Correlation

Meanwhile, in terms of the influence of organizational culture to the job satisfaction of teachers, it was found out that there is a slight positive influence of clan as an organizational culture to the job satisfaction of the respondents. This finding also shows that Catholic Higher Education institutions in the Philippines prioritize a great need for having a clan type as an organizational culture. The table further reveals negative influence between job satisfactions with the other three organizational culture types. This means that an increased level of job satisfaction of teachers yields a lower need for hierarchy, adhocracy, and market. The market culture type shows no significant influence in the job satisfaction of teachers of Catholic Higher Education institutions in the Philippines.

Previous studies on organizational culture stressed that this organizational behavior stands as the center from which all other factors of human resource management and teachers' organizational behaviors are derived (Alvesson, 2016; Hogan \& Coote, 2014). It is also emphasized that organizational culture influences individuals' attitudes concerning outcomes such as commitment, motivation, morale and satisfaction (Gimenez-Espin, Jimenez-Jimenez, \& Martinez-Costa, 2013). Moreover, clan as an organizational culture also revealed as the most dominant culture type of organization in the corporate and business worlds (Belias \& Koustelios, 2014; Schneider, Ehrhart, \& Macey, 2013). With the result of this study, it was found also found out how influential the utilization of clan as a dominant culture type in maintaining higher level of commitment of employees to their organization and also improving their satisfaction to their work among Catholic Higher Education Institutions in the Philippines. 


\section{Conclusions and Implications}

The results of the present study have several and important implications for theory and further research. First, since limited studies had been conducted focusing on the influence of organizational culture to teachers' organizational behaviors (Huey Yiing \& Zaman Bin Ahmad, 2009; Sarros, Cooper, \& Santora, 2008; Hartnell, Ou, \& Kinicki, 2011), the present study, therefore extends this line of inquiry by examining the influence of organizational culture to specific important teachers' organizational behaviors such as organizational commitment and job satisfaction. The result confirms previous studies on organizational culture that indeed, this important indicator plays a very vital role in the sustainability and development of private and Catholic schools (Zheng Yang, \& McLean, 2010), employee retention (Chew \& Chan, 2008), and organizational cultural values (Naranjo-Valencia, Jimenez-Jimenez, \& Sanz-Valle, 2011; Ravasi \& Schultz, 2006).

Second, since most empirical evidence on the influence of organizational culture to teachers' organizational behavior had been conducted mostly in Western countries and in Africa, this study gave very important information since it also extends its inquiry in developing countries by taking Philippines as a case study. The results of the present study also coincide with previous literature revealing clan as the dominant culture type among institutions and organizations in United States (Lund, 2003; Berrio, 2003; Smart \& St. John, 1996), United Kingdom (Ogbonna \& Harris, 2000), Africa (Van der Post, de Coning, \& Smit, 1997), and China (Tsui, Wang, \& Xin, 2006). With these results, it is then suggested that more research be conducted focusing on other types of Higher Educational institutions in the Philippines such as government owned and private non-sectarian schools in order to confirm the claim of the present study and previous studies of the universality of clan as the dominant organizational culture of Higher Education institutions across different nations.

Third, one of the major contributions of this study is that it addresses major gaps in literature since no research studies have systematically examined the influence of organizational culture on teachers' organizational commitment and jobs satisfaction in a single study in educational settings. Most studies conducted in education had studies the influence of organizational culture on either of these two organizational behaviors (Lund, 2003; Huey Yiing, \& Zaman Bin Ahmad, 2009). And based on the findings of this present study, one can already see the high influence of organizational culture to teachers' organizational commitment and also a slight effect of organizational culture to teachers' job satisfaction in school setting taking Catholic Higher Education institutions in the Philippines as a case study. From this perspective, educational managers and administrators can use the information arising out of the findings of the present study to come up with strategies and initiatives to further improve programs and activities focusing on enhancing and developing teachers' organizational commitment and more importantly their job satisfaction. Furthermore, in terms of theoretical perspective, the study gave insights on how organizational culture affects and influences teachers' organizational commitment and job satisfaction. However, organizational culture explains and accounts only for some portion of these two teachers' organizational behaviors. It can then be stressed that other in addition to organizational culture, other factors and indicators may influence teachers' organizational commitment and job satisfaction. It is then highly recommended that future research try to explore the influence of other organizational variables such as supervisory support, communicated vision and mission, schools and community relations, and other school-related variables to teachers' organizational commitment and job satisfaction.

Furthermore, the findings of the study also have important implications for educational administrators and policy-makers. The results clearly stressed how organizational culture foster high level of organizational commitment and even a positive relationship to job satisfaction of teachers. These findings have an important implication in terms of teachers' training and development of school administrators in the Philippines. Furthermore, the results of the study can also serve as a guide for educational human resource managers in coming up with frameworks, evaluation and assessment sheets, and initiatives that will further enhance the organizational culture of institutions that will eventually lead to a higher level of commitment and eventually even a higher level of job satisfaction. And finally, the study will also serve as a mirror to see the status of their teachers along their commitment especially along their job satisfaction since many studies had been concluding that job satisfaction plays an important role in enhancing student learning and in the delivery of quality instructions (Ololube, 2006; Houston, Meyer, \& Paewai, 2006). In this regard, administrators of Catholic Higher Education institutions in the Philippines may consider critical issues in enhancing their teachers' job satisfaction such as improvement in working conditions, salaries and benefits, and more importantly addressing communication problems.

In summary, it is hope that this study has made a vital contribution in understanding the influence of organizational culture to teachers' organizational commitment and job satisfaction in the Philippine educational context especially among Catholic Higher Education institutions. Thus, this study serves as a basis in stimulating further research and studies on the exploration of organizational culture on teachers' organizational behaviors and outcomes in the Philippines and elsewhere. 


\section{REFERENCES}

[1] Ahluwalia, A. K., \& Preet, K. (2016). Organizational commitment amongst the female teachers: A comparison between state and private universities. South Asian Journal of Participative Development, 16(2), 39.

[2] Alvesson, M. (Ed). (2016). Organizational culture. Sage.

[3] Auernhammer, J., \& Hall, H. (2014). Organizational culture in knowledge creation, creativity, and innovation: Towards the Freiraum model. Journal of Information Science, 40(2), 154-166.

[4] Awang, A., Ahmad, J. H., Zin, N. M. (2010). Modeling job satisfaction and work commitment among lecturers: A case study of UiTM Kelantan. Journal of Statistical Modeling and Analytics, 1(2), 45-59.

[5] Azzopardi, E., \& Nash, R. (2013). A critical evaluation of importance-performance analysis. Tourism Management, $35,222-233$.

[6] Balci, A. (2006). Orgutsel sosyallesme kuram strateji ve taktikler. Ankara: Pegem A. Yayincilik.

[7] Belias, D., \& Kostelios, A. (2014). Organizational culture and job satisfaction: A review. International Review of Management and Marketing, 4(2), 132.

[8] Berrio, A. A. (2003). An organizational culture assessment using the competent values framework: A profile of Ohio State University Extension.Age, 2(699), 1-052.

[9] Bogler, R. (2002). Two profiles of schoolteachers: A discriminant analysis of job satisfaction. Teaching and Teacher Education, 18, 665-673.

[10] Brown, D. \& Sargeant, M. A. (2007). Job satisfaction, organizational commitment, and religious commitment of full time university employees. Journal of Research on Christian Education, 16(2), 211-241.

[11] Byun, K. \& Kim, M. (2011). Shifting patterns of the government's policies for the internalization of Korean higher education. Journal of Studies in International Education. 15(5), 467-486.

[12] Calderon, M., Slavin, R., \& Sanchez, M. (2011). Effective instruction for English learners. The Future of Children, 21(1), 103-127.

[13] Callea, A., Urbini, F., \& Chirumbolo, A. (2016). The mediating role of organizational identification in the relationship between qualitative job insecurity, $\mathrm{OCB}$, and job performance. Journal of Management Development, $35(6), 635-746$.

[14] Cameron, K. (2008). A process for changing organization culture. Handbook of Organization Development, 14(5), 2-18.

[15] Cameron, K. S. \& Quinn, R. E. (1999). Diagnosing and changing organizational culture: Based on the competing values framework. Addison - Wesley, Reading, MA.

[16] Canrinus, E. T., Helms-Lorenz, M., Beijaard, D., Buitink, J.,
\& Holfman, A. (2012). Self-efficacy, job satisfaction, motivation, and commitment: Exploring the relationships between indicators of teachers' professional identity. European Journal of Psychology of Education, 27(1), 115-132.

[17] Casimir, G., Ngee Keith Ng, Y., Yuan Wang, K., \& Ooi, G. (2014). The relationships amongst leader-member exchange, perceived organizational support, affective commitment, and in-role performance: A social-exchange perspective. Leadership \& Organization Development Journal, 35(5), 366-385.

[18] Cerit, Y. (2010). The effects of servant leadership on teachers' organizational commitment in primary schools in Turkey. International Journal of Leadership in Education, 13(3), 301-317.

[19] Chan, W. Y., Lau, S., Nie, Y., Lim, S., \& Hogan, D. (2008). Organizational and personal predictors of teacher commitment: The mediating role of teacher efficacy and identification with school. American Educational Research Journal, 45(3), 597-630.

[20] Chew, J. \& Chan. C. C. (2008). Human resource practices, organizational commitment and intention to stay. International Journal of Manpower, 29(6), 503-522.

[21] Collie, R. J., Shapka, J. D., \& Perry, N. E. (2012). School climate and social-emotional learning: Predicting teacher stress, job satisfaction, and teaching efficacy. Journal of Educational Psychology, 104(4), 1189.

[22] Crossman, A. \& Harris, P. (2006). Job satisfaction of secondary school teachers. Educational Management Administration and Leadership, 34(1), 29-46.

[23] Duffy, R. D. \& Lent, R. W. (2009). Test of social cognitive model of work satisfaction in teachers. Journal of Vocational Behavior, 75(2), 212-223.

[24] Ereno, J. R. \& Nunez, K. T. (2014). What makes a teacher a better? A hierarchical regression analysis of self-efficacy and commitment as predictors of faculty members job performance. International Journal of Asian Social Science, 4(4), 492-498.

[25] Evans, L. (2001). Delving deeper into morale, job satisfaction, and motivation among education professionals. Educational Management and Administration, 29, 291-306.

[26] Fatimah, O., Amiraa, A. M., \& Halim, F. W. (2011). The relationships between organizational justice, organizational citizenship behavior and job satisfaction. Pertanika J. Soc. Sci. \& Hum, 19, 115-121.

[27] Fay, D., Shipton, H., West, M. A., \& Patterson, M. (2015) Teamwork and organization innovation: The moderating role of the HRM context. Creativity and Innovation Management, 24(2), 261-277.

[28] Fralinger, B. \& Olson, V. (2007). Organizational culture at the university level: A study using the OCAI instrument. Journal of College Teaching \& Learning, 4 (11), 85-98.

[29] Gimenez-Espin, J. A., Jimenez-Jimenez, D., \& Martinez-Costa, M. (2013). Organizational culture for total quality management. Total Quality Management and Business Excellence, 24(5-6), 678-692.

[30] Gokce, A. T. (2013). Relationship between whistle-blowing 
and job satisfaction and organizational loyalty at schools in Turkey. Educational Research and Reviews, 8(14), 1186.

[31] Hartnell, C. A., Ou, A. Y., \& Kinicki, A. (2011). Organizational culture and organizational effectiveness: A meta-analytic investigation of the competing values framework's theoretical suppositions.

[32] Hatcher, R. (2005). The distribution of leadership in power and in schools. British Journal of Sociology of Education, 26(2), 253-267.

[33] Hemmelgard, A. L., Glisson, C., \& James, L. R. (2006). Organizational culture and climate: Implications for services and interventions research. Clinical Psychology: Science and Practice, 13(1), 73-89.

[34] Herdman, A. O., Yang, J., \& Arthur, J. B. (2017). How does leader-member exchange disparity affect teamwork behavior and effectiveness in work groups? The moderating role of leader-leader exchange. Journal of Management, 43(5), 1498-1523.

[35] Hogan, S. J., \& Coote, L. V. (2014). Organizational culture, innovation, and performance: A test of Schein's model. Journal of Business Research, 67(8), 1609-1621.

[36] Houston, D., Meyer, L. H., \& Paewai, S. (2006). Academic staff workloads and job satisfaction: Expectations and values in academe. Journal of Higher Education Policy and Management, 28(1), 17-30.

[37] Hoyt, J. E. (2012). Predicting the satisfaction and loyalty of adjunct faculty. The Journal of Continuing Higher Education, 60(3), 132-142.

[38] Hu, J., \& Liden, R. C. (2015). Making a difference in the teamwork: Linking team prosocial motivation to learn processes and effectiveness.Academy of Management Journal, 58(4), 1102-1127.

[39] Huey Yiing, L. \& Zaman Bin Ahmad, K. (2009). The moderating effects of organizational culture on the relationships between leadership behavior and organizational commitment and between organizational commitment and job satisfaction and performance. Leadership \& Organization Development Journal, 30(1), 53-86.

[40] Hulpia, H., Devos, G., \& Rosseel, Y. (2009). The relationship between the perception of distributed leadership in secondary schools and teachers' and teacher leaders' job satisfaction and organizational commitment. School Effectiveness and School Imporvement, 20(3), 291-317.

[41] Huysman, J. T. (2007). Rural teacher satisfaction: An analysis of beliefs and attitudes of rural teachers' job satisfaction. (Doctoral Dissertation, University of Central Florida).

[42] John, M. C. (2017). Leadership style, school climate, and the institutional commitment of teachers. International Forum Journal, 1(12).

[43] Joseph, C. M., Buela, S., \& Rajalakshmi, V. R. (2017). Work motivation and organizational commitment of college teachers. Splint International Journal of Professionals., $41(1), 67$.

[44] Jung, T., Scott, T., Davies, H. T., Bower, P., Whalley, D.,
McNally, R., \& Mannion, R. (2009). Instruments for exploring organizational culture: A review of literature. Public Administration Review, 69(6), 1087-1096.

[45] Khan, H., Shah, B., Hassan, F. C., \& Khan, N. (2013). Organizational commitment of teachers and role of their employment traits in the context of higher education institutions of Pakistan. Management Science and Engineering, 7(3), 1-12.

[46] Koch, J. (2016). Organization as communication and the emergence of leadership: A Luhmannian Perspective. Organization as Communication: Perspectives in Dialogue, 121.

[47] Lane, A. \& McAndrew, P. (2010). Are open educational resources systematic or systemic change agents for teaching practice? British Journal of Educational Technology, 41(6), 952-962.

[48] Lazaroui, G. (2015). Work motivation and organizational behavior. Contemporary Readings in Law and Social Justice, 7(2), 66.

[49] Leavey, M. C. (2016). Religious education, school climate and achievement: A study of nine Catholic sixth-form girls' schools.

[50] Lim, T. (2010). Relationships among organizational commitment, job satisfaction, and learning organization culture in one Korean private organization. Asia Pacific Education Review, 11(3), 311-320.

[51] Lindahl, R. (2006). The role of organizational climate and culture in the school improvement process: A review of the knowledge base. Educational Leadership Review, 7(1), 19-29.

[52] Linnenluecke, M. K., \& Griffiths, A. (2010). Corporate sustainability and organizational culture. Journal of World Business, 45(4), 357-366.

[53] Loi, R., Chan, K. W., \& Lam, L. W. (2014). Leader-member exchange, organizational identification, and job satisfaction: A social identify perspective. Journal of Occupational and Organizational Psychology, 87(1), 42-61.

[54] Louis, K. S. (2007). Trust and improvement in schools. Journal of Educational Change, 8(1), 1-24.

[55] Lund, D. B. (2003). Organizational culture and job satisfaction. Journal of Business and Industrial Marketing, 18(3), 219-236.

[56] Malik, M. E., Nawab, S., Naeem, B., \& Danish, R. Q. (2010). Job satisfaction and organizational commitment of university teachers in public sector of Pakistan. International Journal of Business and Management, 5(6), 17.

[57] Masood, S. A., Dani, S. S., Burns, N. D., \& Backhouse, C. J. (2006). Transformational leadership and organizational culture: The situational strength perspective. Proceedings of the Institution of Mechanical Engineers, Part B: Journal of Engineers, Part B: Journal of Engineering Manufacture, 220(6), 941-949.

[58] Mawoli, M. A. \& Babandakko, A. Y. (2011). An evaluation of staff motivation, dissatisfaction and job performance in an academic setting. Australian Journal of Business and Management Research, 1(9), 1. 
[59] Mclerney, D. M., Ganotice, F. A., King, R. B., Morin, A. J. \& Marsh, H. W. (2015). Teachers' commitment and psychological well-being: Implications of self-beliefs for teaching in Hongkong. Educational Psychology, 35(8), 926-945.

[60] Meyer, J. P., \& Allen,N. J. (2001). A three-component conceptualization of organizational commitment. Human Resource Management Review, 1(1), 61-89.

[61] Meyer, J. P., Becker, T. E., \& Van Dick, R. (2006). Social identities and commitments at work: Toward an integrative model. Journal of Organizational Behavior, 27(5), 665-683.

[62] Moynihan, D. P. \& Pandey, S. K. (2007). Finding workable levers over work motivation: Comparing job satisfaction, job involvement, and organizational commitment. Administration \& Society, 39(7), 803-832.

[63] Naderi Anari, N. (2012). Teachers: emotional intelligence, job satisfaction, and organizational commitment. Journal of Workplace Learning, 24(4), 256-269.

[64] Nagar, K. (2012). Organizational commitment and job satisfaction among teachers during times of burnout. Vikalpa, 37(2), 43-60.

[65] Naranjo-Valencia, J. C., Jimenez-Jimenez, D., \& Sanz-Valle, R. (2011). Innovation or imitation? The role of organizational culture. Management Decision, 49(1), 55-72.

[66] Nawab, S., \& Bhatti, K. K. (2011). Influence of employee compensation on organizational commitment and job satisfaction: A case study of educational sector of Pakistan. International Journal of Business and Social Sciences, 2(8).

[67] Nguni, S., Sleegers, P., \& Denessen, E. (2006). Transformational and transactional leadership effects on teachers' job satisfaction, organizational commitment, and organizational citizenship behavior in primary schools: The Tanzanian case. School Effectiveness and School Improvement, 17(2), 145-177.

[68] Ogbonna, E. \& Harris, L. C. (2000). Leadership style, organizational culture and performance: empirical evidence from UK companies. International Journal of Human Resource Management, 11(4), 766-788.

[69] Okpara, J. O. \& Wynn, P. (2008). The impact of ethical climate on job satisfaction and commitment in Nigeria: implications for management development. Journal of Management Development, 27(9), 935-950.

[70] Ololube, N. P. (2006). Teachers job satisfaction and motivation for school effectiveness: An assessment. Online Submission.

[71] Pearson, L. C. \& Moomaw, W. (2005). The relationship between teacher autonomy and stress, work satisfaction, empowerment, and professionalism. Educational Research Quarterly, 29(1), 37.

[72] Perrachione, B. A., Petersen, G. J., \& Rosser, V. J. (2008). Why do they stay? Elementary teachers' perceptions of job satisfaction and retention. The Professional Educator, 32(2), 1

[73] Plohart, R. E. \& Moliterno, T. P. (2011). Emergence of the human capital resource: A multilevel model. Academy of Management Review, 36(1), 127-150.
[74] Raj Adhikari, D. (2010). Knowledge management in academic institutions. International Journal of Educational management, 24(2), 94-104.

[75] Ravasi, D. \& Schultz, M. (2006). Responding to organizational identity threats: Exploring the role of organizational culture. Academy of Management Journal, 49(3), 433-458.

[76] Rayton, B. A., \& Yalabik, Z. Y. (2014). Work engagement, psychological contract breach and job satisfaction. The International Journal of Human Resource Management, 25(17), 2382-2400.

[77] Rose, R. C., Kumar, N., \& Pako, O. G. (2009). The effect of organizational learning on organizational commitment, job satisfaction, and work performance. Journal of Applied Business Research, 25(6), 55.

[78] Ruesch, J. (2017). Communciation: The social matrix of psychiatry. Routledge.

[79] Salehi, M. \& Gholtash, A. (2011). The relationship between job satisfaction, job burnout, and organizational commitment with the organizational commitment with the organizational citizenship behavior among members of faculty in the Islamic Azad University - first district branches, in order to provide the appropriate model. Procedia - Social and Behavioral Sciences, 15, 306-310.

[80] Santhapparaj, A. S. \& Alam, S. S. (2005). Job satisfaction among academic staff in private universities in Malaysia. Journal of Social Sciences, 1(2), 72-76.

[81] Sarros, J. C., Cooper, B. K., \& Santora, J. C. (2008). Building a climate for innovation through transformational leadership and organizational culture. Journal of Leadership and Organizational Studies, 15(2), 145-158.

[82] Schneider, B., Ehrhart, M., \& Macey, W. H. (2013). Organizational climate and culture. Annual Review of Psychology, 64, 361-388.

[83] Schreiner, P. (2015). Religious education in the European context. Crossings and Crosses: Borders, Educations, and Religion in Northern Europe, 63, 139.

[84] Secundo, G., Margherita, A., Elia, G., \& Passiante, G. (2010). Intangible assets in higher education and research: mission, performance, or both? Journal of Intellectual Capital, 11(2), $140-157$.

[85] Skaalvik, E. M. \& Skaalvik, S. (2009). Does school context matter? Relations with teacher burnout and job satisfaction. Teaching and Teacher Education, 25(3), 518-524.

[86] Smart, J. C. \& St. John, E. P. (1996). Organizational culture and effectiveness in higher education: A test of the culture type and strong culture hypothesis. Educational Evaluation and Policy Analysis, 18(3), 219-241.

[87] Somech, A., \& Khalaili, A. (2014). Team boundary activity: Its mediating role in the relationship between structural conditions and team innovation, Group \& Organization Management, 39(3), 274-299.

[88] Tindowen, D. J. (2019). Influence of Empowerment on Teachers' Organizational Behaviors. European Journal of Educational Research, 8(2), 617-631. 
[89] Thang, N. N., \& Fassin, Y. (2017). The impact of internal corporate social responsibility on organizational commitment: Evidence from Vietnamese Service Firms. Journal of Asia-Pacific Business, 1-17.

[90] Thomas, K. A. (2010). Work motivation and job satisfaction of teachers. Southeastern Teacher Education Journal, 3(1).

[91] Thoonen, E. E., Sleegers, P. J., Oort, F. J., Peetsma, T. T., \& Geijsel, F. P. (2011). How to improve teaching practices: The role of teacher motivation, organizational factors, and leadership practices. Educational Administration Quarterly, $47(3), 496-536$

[92] Tolentino, R. C. (2013). Organizational commitment and job performance of the academic and administrative personnel. International Journal of Information Technology and Business Management, 15(1), 51-59.

[93] Tsui, A S., Wang, H. \& Xin, K. R. (2006). Organizational culture in China: An analysis of culture dimensions and culture types. Management and Organization Review, 2(3), 345-376.

[94] Uka, A. (2014). The communication and its influence on the effectiveness of the organization. Mediterranean Journal of Social Sciences, 5(2), 165.

[95] Van der Post, W. Z., de Coning, T. J., \& Smit, E. M. (1997) An instrument to measure organizational culture. South African Journal of Business Management, 28(4), 147-168.

[96] Vandenberghe, C., Bentein, K., \& Panaccio, A. (2014). Affective commitment to organizations and supervisors and turnover: A role of theory perspective. Journal of Management, 0149206314559779.

[97] White, J. C., Varadarajan, P. R., \& Dacin, A. (2003). Market situation interpretation and response: The role of cognitive style, organizational culture, and information use. Journal of Marketing, 67(3), 63-79.

[98] Wiewiora, A., Trigunarsyah, B., Murphy, G., \& Coffey, V. (2013). Organizational culture and willingness to share knowledge: A competing values perspective in Australian context. International Journal of Project Management, 31(8), 1163-1174.

[99] Wiesner, G., \& Yuniarti, N. (2018). Systematic Quality Management in Vocational Educational Institutes: Role of Teachers in Development of Organizational Quality. Jurnal Pendidikan Teknologi dan Kejuruan, 24(1), 162-170.

[100] Wright, P. M., \& McMahan, G. C. (2011). Exploring human capital: putting 'human' back into strategic human resource management. Human Resource Management Journal, 21(2), 93-102.

[101] Yahaya, R., \& Enrahim, F. (2016). Leadership styles and organizational commitment: Literature review. Journal of Management, 35(2), 190-216.

[102] Yamauchi, F. (2005). Why do schooling returns differ? Screening, private schools, and labor markets in the Philippines and Thailand. Economic Development and Cultural Change, 53(4), 959-981.

[103]Yucel, I \& Bektas, C. (2012). Job satisfaction, organizational commitment and demographic characteristics among teachers in Turkey: Younger is better?. Procedia - Social and Behavioral Sciences, 46,
1598-1608.

[104]Zbirenko, A., \& Andersson, J. (2014). Effect of organizational structure, leadership, and communication on efficiency and productivity: A qualitative study of a public health-care organization.

[105]Zheng, W., Yang, B., \& McLean, G. N. (2010). Linking organizational culture, structure, strategy, and organizational effectiveness: Mediating role of knowledge management. Journal of Business Research, 63(7), 763-771. 